use are primarily responsible for these high rates of automobile death and injury. National surveys of booster seat use have noted regional differences; however, research on influences for usage is limited. This study examined influences on parents decision making for booster seat use in two Canadian provinces; British Columbia and Manitoba. British Columbia has recently legislated use of booster seats while Manitoba has not. Although parents in both provinces did not differ on the perceived safety benefits of using booster seats they did significantly differ on their intent to use them. Parents in British Columbia were significantly more likely to report they would always make sure their child rode in a booster seat. Parents perception of barriers to using booster seats did not differ significantly with one exception; Manitoba parents were more likely to perceive that children were teased for riding in booster seats. British Columbian parents reported significantly higher exposure to multi media messaging about booster seats and knew booster seats were legally required for children under 9 years of age. In contrast, Manitoba parents were confused regarding whether their province had booster seat legislation and had less exposure to messaging about booster seat safety. The results suggest that legislation and knowledge of the legislation for booster seat use may impact usage within Canada.

\title{
0633 INJURY PREVENTION/CHILD PASSENGER SAFETY: FACTORS INFLUENCING PARENTS' CORRECT AND CONSISTENT USE OF BOOSTER SEATS
}

HCorreale* EClark, CCPiotrowski, LWarda, BBruce, CECunnigham Correspondence: University of Northern British Columbia, 3333 University Way Prince George, BC, V2N 4Z9, Canada

\subsection{6/ip.2010.029215.633}

School aged children in Canada are ten times more likely than any other age groups to experience death or severe injury in road crashes. Misuse of safety seats and lack of booster seat 